\title{
Problems with the implementation of Adat Basandi Syarak Syarak Basandi Kitabullah philosophy
}

\section{Permasalahan implementasi falsafah Adat Basandi Syarak Syarak Basandi Kitabullah}

\author{
Asrinaldi \& Yoserizal \\ Department of Political Sciences, Faculty of Social and Political Sciences, Universitas Andalas \\ Address: Limau Manis, Pauh, Padang, West Sumatra 25163 \\ Email: asrinaldi4@yahoo.com
}

\begin{abstract}
This study discusses the problems of West Sumatra's local governments in the practice and implementation of Adat Basandi Syarak Syarak Basandi Kitabullah (ABS-SBK) tradition philosophy in the West Sumatra regional medium-term development plan in 2016-2021. The purpose is to organize the program and activities developed in the regional budget. This study analyzes the $A B S-S B K$ tradition philosophy practice in West Sumatra government administration. This study uses a descriptive qualitative method; moreover, the data collection in this study uses semi-structured interviews related to the practice of $A B S-S B K$ tradition philosophy. This study interviewed 14 informants consisting of customary stakeholders, religious leaders, bureaucrats, academics, women (bundokanduang), and community leaders. In determining the informants, this study uses a purposive sampling method conducted in Agam Regency and Limapuluh Kota Regency in West Sumatra Province. This study found that four factors influence the implementation and practice of the $A B S-S B K$ tradition philosophy in the government level: 1) the absence of apparent $A B S-S B K$ tradition philosophy substance values, 2) the traditional transcendental and profane values of the traditional and sharia institution did not work very well in maintaining and preserving Minangkabau traditional values, 3) the absence of individual consensus and commitment toward $A B S-S B K$ philosophy, and 4) the poor and minimum $A B S-S B K$ tradition philosophy implementation at the government level. People interpret and translate this philosophy according to their understanding since no specific guidelines govern their interaction. This fact is understandable and reasonable since it is part of their life. The same goes for the government level, the absence of the guidelines causes a poor and minimum effort in their development program using $A B S-S B K$ tradition philosophy as the basic. It also leads to a consensus between customary and religious institutions. The government finds it challenging to translate this philosophy into their programs and activities development so that they cannot directly refer their programs to this original philosophy from Minangkabau.
\end{abstract}

Keywords: Adat Basandi Syarak Syarak Basandi Kitabullah (ABS-SBK); local government; customs; implementation; Minangkabau

\section{Abstrak}

Penelitian ini membahas kesulitan pemerintah daerah di Sumatra Barat, menggambarkan misi mempraktikkan filosofi Adat Basandi Syandi Basandi Kitabullah (ABS-SBK) yang terkandung dalam rencana pembangunan jangka menengah daerah Sumatera Barat tahun 2016-2021, hal ini bertujuan untuk mengatur program dan kegiatan pembangunan ke dalam Anggaran Pendapatan dan Belanja Daerah (APBD). Penelitian ini bertujuan untuk menganalisis praktik filosofi ABS-SBK dalam administrasi pemerintahan di Sumatera Barat. Penelitian ini menggunakan metode deskriptif kualitatif dan data yang dikumpulkan dalam penelitian ini menggunakan wawancara semi-terstruktur terkait dengan praktik filsafat ABS-SBK. Penelitian ini mewawancarai sebanyak 14 informan yang terdiri dari pemangku kepentingan adat, tokoh agama, birokrat, akademisi, perempuan (bundokanduang), dan tokoh masyarakat. Dalam menentukan informan penelitian ini menggunakan metode purposive sampling yang dilakukan di Kabupaten Agam dan Kabupaten Limapuluh Kota di Provinsi Sumatera Barat. Studi ini menemukan bahwa ada empat faktor yang mempengaruhi implementasi filosofi ABS-SBK dalam praktik pemerintahan, 1) belum adanya kejelasan substansi nilai-nilai dari filosofi ABS-SBK, 2) lembaga adat dan sarak yang memelihara dan melestarikan nilai-nilai tradisional Minangkabau yang terdiri dari nilai transedental dan profan belum bekerja dengan baik, 3) belum adanya konsensus dan individu komitmen terhadap filosofi $A B S-S B K$, dan 4) lemahnya praktik filosofi ABS-SBK dalam pelaksanaan fungsi-fungsi 
pemerintah daerah. Sejauh ini, orang hanya memahami filosofi ABS-SBK sesuai dengan pemahaman mereka karena belum adanya pedoman yang mengatur pola interaksi mereka. Pemahaman ini masuk akal karena filosofi ABS-SBK telah menjadi perilaku sehari-hari masyarakat. Begitu juga dengan pemerintah daerah akan dapat memahami substansi secara menyeluruh nilai filosofi ABS-SBK jika ada pedoman yang dapat menjadi dasar dalam mengembangkan program pembangunan. Pedoman ini tidak diragukan lagi berasal dari pengembangan substansi nilai filosofi ABS-SBK ini. Tidak adanya pedoman filosofi ABS-SBK ini menyebabkan terbentuknya konsensus di antara lembaga adat dan lembaga agama. Filosofi ABS-SBK yang tidak jelas menjadi kesulitan pemerintah daerah sehingga program dan kegiatan pembangunan tidak terkait langsung bagaimana menerapkan filosofi ABS-SBK yang tumbuh dan berkembang di masyarakat Minangkabau.

Kata kunci: Adat Basandi Syarak Syarak Basandi Kitabullah (ABS-SBK); pemerintah daerah; adat; implementasi; Minangkabau

\section{Introduction}

The philosophy of Adat Basandi Syarak Syarak Basandi Kitabullah (the tradition of Bersendi Syarak-Syarak Bersendi Kitabullah, hereafter referred to $A B S-S B K$ ) is a value system that guides the interaction between individuals with their environment based on Islamic and customary values. Although the customs and culture are the result of human initiative and thinking, they still refer to Islamic sharia or teachings, which are the primary identity of the Minangkabau ethnicity (von Benda-Beckmann \& von Benda-Beckmann 2012). In agreement, Abidin (2016) also explained that the $A B S-S B K$ philosophy and Minangkabau people have civilized Muslim characteristics. The $A B S$ $S B K$ became the basic concept of adat nan sabana adat (the fundamental values of the Minangkabau ethnic customs that rely on Islamic values), it was revealed through kato pusako (adage), and these customs influenced public attitudes and community standard procedures.

Identifying when this $A B S-S B K$ philosophy began to be used as a guideline in the life of the ethnic Minangkabau is not an easy task. Referring to tambo (historical literary), following the entry of Islam brought by Aceh traders into the Minang realm, at that time an agreement was held between Acehnese traders who developed Islam in the Minang realm with the tradition so that they could preserve their customs and culture due to this interaction. It is where the connection between religion and tradition began with the philosophy of $A B S-S B K$.

Amran (1981) asserted that the ABS-SBK philosophy emerged following the end of the Padri War, which lasted for thirty years. Historically, the Padri War wanted to purify religious practices in the Minangkabau area, mixed with shirk (a sin of idolatry or polytheism) and bid'ah (innovation in religious matters) carried out by indigenous peoples who were still influenced by old Minangkabau traditions. This situation brought catastrophe and conflict between Islamic teaching and traditional practices that led to war because the Padri tribes were against the practices. The compromise between the Padri and the Adat in resolving this never-ending conflict raises a paradox, as explained by Hadler (2010):

"Conventional historiography illustrates that the Padri stopped only by the intervention of the Dutch military in favor of the traditionalists, that the Minangkabau had to choose between their cultural destruction at the hands of Islamic puritans or surrender to a colonial state. However, that is not the case. The Padri's defeat was not due to Dutch pressure, but rather due to the emergence of a new response to Mecca's ideological shift and the desire of a Padri leader who regrettably wanted to find a compromise between Islam and matriarchal customs."

As predicted, the end of the war between the Padri and the indigenous peoples was marked by an agreement between the two parties at Marapalam Hill, Pato Peak in Lintau Buo, Tanah Datar District. This agreement is also known as the Satie Bukit Marapalam Oath, which is the underlying implementation of the philosophy of $A B S-S B K$, syarak mangato (gives law), and adat mamakai (custom practice it). Since then, the $A B S-S B K$ philosophy has been agreed to be the basis of the Minangkabau ethnic life until now (Hasanuddin 2013).

The $A B S-S B K$ philosophy began to lose its meaning and identity because of the influence of global culture as a guide in living life for the Minangkabau ethnics. Many aspects of Minangkabau ethnic 
life in modern times no longer refer to $A B S-S B K$ values. The regional government, as the agent of perseverance and safeguard institution, apparently has not been able to carry out its role to help preserve the $A B S-S B K$ philosophy due to the changing times. Likewise with traditional institutions such as Kerapatan Adat Nagari (KAN) or Nagari Adat Council at the nagari level (a division of administrative areas after subdistricts in the West Sumatra Province) and the Lembaga Kerapatan Adat Alam Minangkabau (LKAAM) or Adat Organization of the Minangkabau World at the provincial level have not been able to carry out their functions properly. The same thing also happened to the Majelis Ulama Indonesia (MUI) or Indonesian Ulama Council as a sharia institution in regencies or cities and provinces that did not specifically oversee the implementation of the $A B S-S B K$ philosophy. For instance, at the regional level, there are not many programs and activities that directly intersect with the implementation of this customary philosophy. It is due to the absence of the $A B S-S B K$ philosophy application module as a guideline that can be followed by local government officials (Sekretariat Dewan Provinsi Sumatera Barat 2017).

Whereas in the regional development documents, such as the Regional Long-Term Development Plan (RLTDP) 2005-2025 and the Mid-Term Development Plan (MTDP) of West Sumatra Province, which is changed every five years, the $A B S-S B K$ philosophy is the central pillar in implementing existing development missions. Does this fact lead to the question as to why has not the local government been able to implement the $A B S-S B K$ philosophy in the form of development programs and activities in the community? What factors influence the successful implementation of the $A B S$ $S B K$ philosophy? These are among the questions that will be explained in this article.

The history of $A B S-S B K$ philosophy in the Minangkabau ethnic life of various versions has been going on for a long time. Some sources have even argued that the implementation of $A B S-S B K$ in the life of the Minangkabau people had been found around the 15th century. Even so, there is another version that is also believed to be accurate. That the $A B S-S B K$ philosophy existed after the Padri War involving indigenous peoples supported by the Dutch colonialists and the ulama (religious leader) who wanted to clean up the Minangkabau ethnic, religious practices. The agreement between the tradition and the ulama is in the Bukit Marapalam Declaration, which is considered to be the basis of the $A B S-S B K$ philosophy (Amran 1981, Fithri 2013). In this case, according to Navis (2017):

"After various violent and revolutionary conflicts and clashes, a consensus was born to put ulama on an equal degree with the leader. In this case, the leader regulates traditional affairs and customary law, while the ulama regulates religious affairs and Islamic law. Both go hand in hand, propping up, following the pattern of cultural dichotomy they profess. The tradition of bersendi syarak syarak bersendi kitabullah became the slogan since then."

The intermingling between Islamic customs and the religion in the Minangkabau community still leaves ambiguity issues inherited from generation to generation in its development process. For instance, concerns regarding power and authority in daily life are the power of a mamak, a mother's brother in the matrilineal system, and his nephew, who is his sister's (mother) (Amir 2011). The question being, whether the power of mamak is more dominant than the power of his biological father. It relates to the understanding of the essence of the $A B S-S B K$ philosophy, which places the mamak as a role model for her nephew, as is written in the philosophy, which is anak dipangku kamanakan dibimbing (children are to be spoiled, nephews are to be guided) (Hasanuddin 2013). Not to mention the issue of inheritance law in Minangkabau, which is also ambiguous if it is related to the inheritance system in Islam. In the Minangkabau tradition, the women get more than the men, which contradicts the inheritance in Islamic law that the men get more inheritance than the women. Meanwhile, in the context of power, men are more dominant than women in the Minangkabau ethnic group (Navis 1984).

On the other side, the $A B S-S B K$ philosophy is also carried out in the implementation of the tungku tigo sajarangan (the elements in the Minangkabau community as leaders consisted of adat leaders, clever people and religious or ulama figures) function, which represents the elements of religious scholars, talented people, and ninik mamak (traditional headman). These three elements have a strong 
influence on the administration system in West Sumatra. These three functions have a complementary function even though their elements are different. For instance, Islamic religious scholars describe how sharia Islam in the daily lives of the Minangkabau people. Such as ninik mamak, who shows and represents both the function and implementation of the Minangkabau tradition. Meanwhile, regular scholars' function is to balance the role of both the ulama and ninik mamak and not to emphasize either more in the $A B S-S B K$ philosophy.

The practice of the $A B S-S B K$ philosophy is more likely to strengthen the Minangkabau ethnic identity in the nation and state practice in a broader context. Looking back at history, some figures, such as Mohammad Hatta, Mohammad Natsir, Sutan Syahrir, and Tan Malaka, became an inseparable part of the establishment of the unitary state of the Republic of Indonesia. Their influence and thoughts are very much felt in every discussion and debate among the other founding fathers, especially when it comes to the Indonesian constitution. Since they were raised with these traditional philosophical values, it made them charismatic leaders (Anwar 2011, Dzulfikriddin 2010, Poeze 2010, Rose 2010). We can find the $A B S-S B K$ philosophy implementation in nagari as a public space; this is where this philosophy is developed. Nagari is Minangkabau's customary law, which implements the Minangkabau tradition as a fundamental principle in government. Since the government issued the Law No.6 of 2014 concerning the villages in Minangkabau, it opened up nagari opportunities to become adat nagari. Especially regarding the historical aspects and specificity of the nagari in West Sumatra with its genealogy (von Benda Beckmann \& von Benda Beckmann 2013, Vel \& Bedner 2015).

Tegnan (2015) also sees the nagari as the basis for developing Minangkabau tradition as well as a place to protect its identity as seen from their control of tanah ulayat (customary land). However, following the inclusion of capitalist economic values, the entrepreneurs avoided conflict by utilizing the ulayat nagari land using incongruence values, which contradict their nagari values. The unavoidable conflict happened since both the nagari authorities and local government evicted them from the land. The keen interest of the community shows how they highly respect their customs and culture in their daily lives. Although Tegnan (2015) did not specifically discuss the relation between these traditional values and the $A B S-S B K$ philosophy, the fundamental values of $A B S-S B K$ have been developed in West Sumatra Villages.

This $A B S-S B K$ philosophy becomes part of the necessary custom for the society, specifically related to the true nature of tradition (adat nan sabana adat) for the Minangkabau ethnicity. However, in the modern context as it is today, its practice is still far from expected. Even local governments have difficulty translating the $A B S-S B K$ value into government programs and activities following the RLTDP that has been agreed with by the West Sumatra Provincial Parliament. Likewise, with the parameters that can be used to measure its success. Even so, the regional government of West Sumatra Province also made a Regional Action Plan (RAP) for the $A B S-S B K$ movement, which started as a description of the existing 2010-2015 RLTDP. Unfortunately, even though this action plan has been made, it does not seem to cover all the problems in government practices, especially in the community. For instance, the traditional education values for the younger generation are not funded thoroughly by the West Sumatra Provincial Government. There is the problem of applying customary law, as in Bali, which is not a priority implemented by the government of the West Sumatra (Samad 2018).

Minangkabau people uphold their customs and culture, especially when they interact with their environment in general. Moreover, these value systems contain values that encourage individuals to act for both the good of society and themselves. It is generally known that the $A B S-S B K$ value system they believe in has the essence of goodness for themselves and the common interests that practice it. Moreover, the rest is based on the Islamic religion and Minangkabau culture, which are part of their daily activities. It is following Weber (1992), who saw the existence of individual beliefs that could influence their motivation to act under their rational interests. Weber believed that the Protestant ethic influences the way individuals develop the company and participate in trading wealth for investment. In addition, the Protestant ethic has become part of the value system that individuals practice as the drivers of capitalism in the world. It is in contrast to followers of other religions which 'limit' the 
accumulation of wealth, especially to pursue world life. Weber (1992) demonstrates that Protestants pursue rational economic benefits and develop positive moral values to develop the spiritual aspects they believe. However, criticism is also directed at Weber's (2012) work, because the study is not considered to explain Protestant ethics in detail and is even considered a preliminary study related to the value system that individuals believe.

Weber's (1992) logic related to Protestant ethics can be analogous to the aspects of $A B S-S B K$ practiced by the Minangkabau ethnic group. If they implement tradition as an individual value system, then the social problem will not exist in society. Moreover, this traditional value system derives from both the Quran and Hadith, which are the central beliefs of the Minangkabau people. However, the fact is that the practice of $A B S-S B K$, which is often referred to by the political elite, and regional government in West Sumatra, contradicts each other. This course, Weber (1992) explained in more depth by comparing how Europeans practiced Protestant ethics, which influenced their society in economic activities. Assuming this philosophy can also be traced through European civilization; thus, we can see the comparison of how the people practice this value system now and before. The point is how the practice and implementation of this philosophy in the development program and activities for the local government sector is performed.

The absence of further explanation regarding 'ABS-SBK value substance' is the problem in the community. It also has an impact on local governments' ability to explain this customary philosophy in government practices. Following the principles of governance, the existence of these guidelines becomes the direction for a government to realize the state's goal. Good governance practices derive from their pulik (the two sides are equally strong, same thing, the same peerless), especially on how to implement policies (Croley 2008). Precise guidelines for the bureaucracy are essential in an autonomous regional government implementation because it has a substantial impact on its results performance. It is a challenging fact for the regional government in West Sumatra.

Indeed, this philosophy could be the primary source of local government policy guidelines. If they can translate this philosophy into regional regulations and public policies, the local government program activities will refer to these. As it is known, public policy, in a pure sense, is comprised of some government activities carried out directly or through its agents and affect people's lives (Peters 1999). Therefore, the implementation of this philosophy has to be the local government's official policy. However, the absence of guidelines for local governments has an impact on the implementation of this traditional philosophy. Besides, commitment and consensus related to this customary philosophy are not well-developed in the community, especially in the nagari.

\section{Research Method}

This study uses a qualitative approach by emphasizing the description aspects related to the studied problem. This descriptive qualitative approach emphasizes the identification and illustrates how a phenomenon occurs through the compilation of relevant data. The analysis uses etic and emic methods, accurately to describe, explain, and validate the research findings. This paper also uses in-depth interviews with several relatable, knowledgeable, and resourceful informants in the data collection process. Further, semi-structured interviews were carried out with 14 informants from different backgrounds, such as traditional leaders, religious leaders, community leaders, and government officials who focused on traditional and cultural matters in the government administration and academics. The author conducted this research from May 2017 until September 2017 in Tanah Datar District and Agam District. These two districts are called luhak (a place or area where Minangkabau ethnicity and culture come from or a place of origin), which is the epicenter district of the Minangkabau tradition and culture. Moreover, this research focuses on the acculturation of tradition and culture in Padang City, where some traditions and cultures meet in this tanah rantau. Padang City has a significant influence on $A B S-S B K$ philosophy. This research also conducts observations related to the activities of the Regional Government Working Unit (RGWU) to complete the interview data, especially those having concerns in tradition, culture, and religious activities. 


\section{Result and Discussion}

The $A B S-S B K$ philosophy is indeed still a polemic in the community. Some think that this is only a jargon for Minangkabau ethics since it does not exist in practice. The absence of this philosophy practice in the implementation stage, both in the administration of government and the life of the West Sumatra people, is one of the impacts of the lack of detailed explanation related to the substance of the $A B S-S B K$ values. This value has universal values, resulting in general interpretation (Asrinaldi 2017). Most of the speeches by the headman in mamangan adat or traditional marriages are wisdom poems. Moreover, if the values refer to Quran and Hadith, society considers this as part of $A B S$ $S B K$ philosophy. It is one of the ways it becomes part of the values in alam takambang jadi guru (traditional term means make the universe as the law and teacher) philosophy. It becomes a reference to study some other values existing as the main principle in $A B S-S B K$ philosophy, especially for the Minangkabau ethnic group (Hakimy 2001). However, this dimension is too general as a study reference and lacks specific guidance for society to study philosophy. Furthermore, the Regional Government Work Unit (RGWU) has not officially made this philosophy a reference for creating and compiling a set of relevant programs and activities for the people in West Sumatra, E stated:

\footnotetext{
"The basic problem in outlining the $A B S-S B K$ philosophy is because there is no clear reference to what values can be used as the basis for the programs and activities developed by the RGWU. As a result, RGWU translates them individually according to their individual needs. Therefore, it is difficult to know whether the programs and activities made by RGWU are already relevant to the $A B S-S B K$ philosophy."
}

These two rather general values and substance in interpretation have impacted the Minangkabau ethnic group toward the consensus and society values itself. This customer values consensus has become an endless polemic among opposing groups against a value that has developed in society historically. We can see it in the daily practice in the nagari. Every nagari has a different point of view in interpreting the values and the substance in society. Moreover, $A B S-S B K$ philosophy is also part of the consensus because of this ongoing internal debate (Hasanuddin 2013). Additionally, the lack of commitment to implementing these customs values and cultures becomes a problem for this philosophy. Moreover, it has not had a 'deal' in the West Sumatra tradition and sharia institution level regarding what kind of $A B S-S B K$ substance values, in the way that Muslims have the Quran and Hadith. Some scholars associate the presence of the guideline with tambo, which is an inseparable part of the Minangkabau history and ethnic development. M stated:

\footnotetext{
"As is commonly known, to understand this philosophy, we can trace it from the Minangkabau ethnic called tambo, which implicitly shows how the Minangkabau ethnic interacts with their environment. Nevertheless, this tambo must also be elaborated again by looking at the current context of the values it contains."
}

The absence of the $A B S-S B K$ philosophy, both in the society and the local government, has aroused much attention from many parties. The regional government has made various attempts to implement this philosophy using its interpretation. However, several factors become obstacles among the fundamental issues in doing so, first, regarding the $A B S-S B K$ substance values. Second, related to the traditional institutions and existing sharia in the community. Third, the commitment and consensus in implementing it. Fourth, how to implement it at both the society and government level.

\section{The substance of $A B S-S B K$ philosophy value factors}

One of the ongoing debates in society about what $A B S-S B K$ philosophy is. Then, what are the $A B S$ $S B K$ values? More than a few people only hear the term $A B S-S B K$, but do not know how to explain it. Both the local government and the community leader mention it frequently; however, when digging deep, each has a different answer. They are even debating the agreement of this philosophy since there are no particular guidelines for them that can be followed. As a result, the emergence of many ambiguities and interpretation toward these values still exist because everyone can interpret it depending on their capability. 
The difficulties in determining and making this philosophy as community guidelines, especially for Minangkabau ethnic, remain. If they can identify and agree on these values, it can become a guideline, especially in government administration. Moreover, in the development and activities programs at the government level, the $A B S-S B K$ philosophy has become a mission. The first West Sumatra RLTDP mission 2016-2021 is improving a harmonious, religious, civilized, and cultured lifestyle based on the philosophy of $A B S-S B K$. The implementation of this mission, for example, in the 2015 West Sumatra Regional Revenue and Expenditure Budget, was broken down into nine programs and 43 activities with a budget allocation of 13.504.936.695 IDR (Badan Perencanaan Pembangunan Daerah 2016). Unfortunately, most of the programs were only coordination, outreach, information dissemination, data collection, monitoring, and evaluation. Meanwhile, the direct programs and activities in the society's interests were rarely present and did not get the local government's attention. It is due to the absence of specific guidelines as to the $A B S-S B K$ philosophy is based on the substance of existing values.

The local government programs and activities action in conducting this first mission was too general and tended to be lacking in the substance of the values. For instance, the indigenous community empowerment institutional improvement program merged into other programs and activities like empowerment, preservation, and development of customs and cultural community Values. This activity spent a budget of 1.278.341.063 IDR with a target of 600 participants (Badan Perencanaan Pembangunan Daerah 2016). Indeed, the indigenous institutional empowerment must refer to what kind of substance values have to be developed to strengthen the customary institutions.

The government faces some obstacles in identifying the substance of $A B S-S B K$ philosophy as a guideline in developing programs and activities. First, related to the $A B S-S B K$ philosophy nature, adat nan sabana adat (the real customary tradition), which tends to be universal values. How to describe the values' universality into reference guidelines for both the government and society is still a big problem. Second, the implementation scope is also an issue in how to identify the $A B S$ $S B K$ philosophy. The Minangkabau people customarily hold the implementation of these values and philosophies in the nagari. The existence of a healthy, guided, traditional institution in the nagari helps preserve, maintain, and implement the existing values. It is different from the practice of $A B S$ $S B K$ in urban areas whose value systems have been influenced by global values, and their traditional institutions are increasingly losing their role. Not all of the urban communities have the nagari indigenous density, which will maintain and preserve the $A B S-S B K$ values as in the nagari.

The difficulty in identifying the $A B S-S B K$ philosophy values as guidelines for implementing regional government programs is one of the critical issues as to why this $A B S-S B K$ philosophy is still as jargon in the community's view. Therefore, the effort to identify the $A B S-S B K$ philosophy values is the first step needed to be done by all parties, the $A B S-S B$ values can be implemented in the community and the administration of government. Moreover, the dimension of the $A B S-S B K$ philosophy values becomes a central guideline in implementing it, especially for the Minangkabau society as well as governance practices.

\section{Tradition and sharia institutional factors}

The Minangkabau customs and futures are well developed in the nagari. They become society's identity, especially in nagari. There is a collective term called adat salingka nigari (tradition applies in a nagari and does not apply outside the nagari territory). It means, every tradition in nagari is unique and special, which can differentiate one from another. For instance, the wedding ceremony and tradition are different among nagari. There are also other ceremonial activities held to show their identity (Hakimy 2001). Furthermore, Hakimy (2001) explains that a nagari is a unified customary community that puts deliberation and consensus-based on the decision-making process in the society. In addition, it is not the only identity but also people's pride and honor because of the consensus they have made together (Benda-Beckmann \& Benda- Beckmann 2013).

The consequence of the customs and cultures practice has an essential role in strengthening the existing social and customary institutions in the nagari. Every customary social and institutional 
institution in the nagari created not only to preserve the traditions and culture in nagari, but also as a traditional guardian to maintain the sustainability and existence of society's values. Simply put, social institutions are behavioral systems and relationships created from society's activities to achieve a specific community goal. The individual interactions within the community are regulated by agreed norm systems to embody and create community harmonization.

The custom and tradition developed in the society can identify the Minangkabau social institution. For example, the tradition of customary laws still exist and are sustainable and strongly believed by the nagari society today. The practice of customary law has regulated the resource balance and harmony concerning economic, social, and political matters in the nagari. Moreover, in the implementation of Law No.6 of 2014 concerning villages, the government pays attention to the social and institutional foundations of the community in the village or nagari. However, the social institution, which should be an essential part of strengthening the philosophy, has not been fully implemented for the sake of governance interest.

Based on West Sumatra Province Regional Regulation No.2 Year 2007 regarding nagari governance, this practice in West Sumatra marginalizes the role of traditional institutions and has indirectly impacted the absence of nagari's social institution. As stated in regional law No.2 Year 2007, which only pays attention to the modern government implementation at the lowest level, it means that the organization of nagari as Minangkabau identity has not given them full enough room to play a role in implementing their customs and cultures (Asrinaldi \& Yoserizal 2013). It also influences the social institution function as well as the traditional institution in preserving the $A B S-S B K$ philosophy.

The social institution dimension of the regional government administration has not received full attention, especially the programs and activities implementation. Looking back at the 2016 West Sumatra Provincial Government Budget, there was only one program related to the social institution and customary institution strengthening program: traditional institutions, arts and culture empowerment programs, and indigenous people's institution empowerment program. Unfortunately, these activities are not likely related to the social institution's and customary institutions' perseverance and sustainability of the $A B S-S B K$ philosophy practice. The consensus problem among individuals or the Minangkabau ethnic group is the main prerequisite to implement the $A B S-S B K$ philosophy. Moreover, the absence of consensus related to this philosophy at governance context becomes a vital attitude to maintain the Minangkabau's values, whether it is the agreed guidelines or a statement. Let alone the low number of Minangkabau ethnics who realize these shifting values, especially the younger generation.

\section{Consensus and commitment factor towards $A B S-S B K$ values}

The progressive and advanced changes in communication and technology have impacted the Minangkabau ethnic attitude and behavior. There are many shifting values systems in society, especially in nagari. For instance, Asrinaldi et al. (2016) found that the mamak's role in educating nephews was greatly diminished and replaced by a father figure at home. Moreover, the interaction among boys in the mosque with their peers is no longer usual and becomes part of their mental maturity. Otherwise, this kind of activity among them is no longer relevant nowadays.

Implicitly, the Minangkabau people still strongly acknowledge their traditional values. However, the problem is how this values consensus will be implemented to be both social and local government commitment. Indeed, the consensus issue is of concern, since, after the Satie Bukik Marapalam Oath agreement related to $A B S-S B K$ philosophy, there has been no consensus created. Moreover, the $A B S-S B K$ universality values impact the Minangkabau ethnics'commitment to implementing it. In addition to this Satie Bukik Marapalam Oath agreement, the lack of the scholarly intervention is seen, which is why they need to reconstruct the consensus involving all of the tungku tigo sajarangan elements as the first Minangkabau social institution as stated by arangan which became the social infrastructure of the Minangkabau people. It confirmed by Bahar \&Tadjoeddin (2004): 


\begin{abstract}
"Something is interesting with the formulation of the agreement mentioned the role of the scholars. Although they were present in the rapek (meeting), none of the clauses and specific norms were explicitly categorized for those prominent people. Thus, the ulamas and the local leader who made the decision. It can be said that the agreement does not bind the scholars. These deficiencies need to be accommodated in the later Rapek Sakato Alam II. Since there are a huge interest and potentials from the locals, so they are willing to develop their hometown nowadays."
\end{abstract}

Renewing the consensus on the $A B S-S B K$ philosophy amid the influence of globalization and new values shifting is needed since those new values change the perspective and point of view of some of the younger generation toward $A B S-S B K$ philosophy. It is even worse if one of them is in the government sector; they will likely neglect the philosophy of the implementation of program and activities development, as has been seen from the new programs and activities. The absence of both consensus and commitment makes this philosophy only as a symbol for most of the Minangkabau ethnicities. In order to construct consensus and commitment, the local government's role is needed to facilitate it and make it into part of its programs and activities. Indeed, the customary and sharia institutions have not been running optimally in society. The institutionalization of these institutions tends to be informal since there are limited facilities, targets, and budgets to implement it. As B explains:

"In overseeing the implementation of the $A B S-S B K$ value in the life of the Minangkabau community, there are indeed institutions that exist, such as the nagari indigenous density, the Minangkabau indigenous and natural density institution. However, all of these institutions are informal institutions. Therefore the government does not fully provide a budget for the activities of these institutions. In addition, ministerial regulations also prohibit local governments from assisting such institutions. That is the difficulty faced by traditional institutions in the nagari to deal with preserving common values such as the $A B S S B K$ philosophy.

In constructing both consensus and commitment, not only do we need to involve the religious and traditional institutions but also the local government needs to play a role in supporting both such institutions. Unfortunately, the West Sumatra local government only provides training and issue management for the society in their official program and activity.

\title{
$A B S-S B K$ practice factor in society
}

The uncertainty of what should be done and what kind of values can be measured is one of the difficulties in measuring how strong is the practice of the $A B S-S B K$ philosophy. It is not only about quantitative measurement, but also qualitative data regarding what values still exist and are sustainable in society. As explained above, if they think that the philosophy is equal and identical to the society's customs and cultures, it means that there is a precise shifting to the values and that Minangkabau ethnics rarely practice it, and it is no longer of concern.

This reality is worrying because global values penetration has influenced the younger generation's way of thinking and attitude - especially Minangkabau ethnic groups who live in the city. These values' acculturation changes the appearance and looks of the Minangkabau younger generation in defining their identity. As long as the absence of $A B S-S B K$ philosophy still exists, the more difficult for the parties who concern about this to identify whether they need to preserve, maintain, and even further develop it in this modern era. It is not enough if the society only practices this philosophy without understanding its meaning; they need to absorb and fully understand this philosophy to be their life's guidelines. Moreover, they need to consider this as an 'ideology and update it to make it relevant in the modern era. The same goes for Pancasila as a nation and state ideology, which has to be explored and understood deeper to remain relevant to Indonesian lives (Latif 2011).

Likewise, the local governance context, we can start the $A B S-S B K$ philosophy practice by involving it in local government programs and activities to trigger community involvement. Let alone the West 
Sumatra's development file, which puts this philosophy as their first mission to develop their regions. To succeed in this mission, every local government arranges a related program to this philosophy, referred to as the strategic plans for local government organizations and the philosophy guidelines practice. Even so, to date, they still have not completed, so we will not see any real proof that they were doing it. The fact that there are still public complaints because of the minimum government implementation toward this philosophy shows there is a tendency that they have not been working on it optimally. In addition to that, society finds it difficult to explore this philosophy into suitable development programs and activities according to its needs (Samad 2018). Figure 1 explains the relation of the four factors which determine how this $A B S-S B K$ philosophy works at the government level; thus, there is still some obstacle in its implementation.

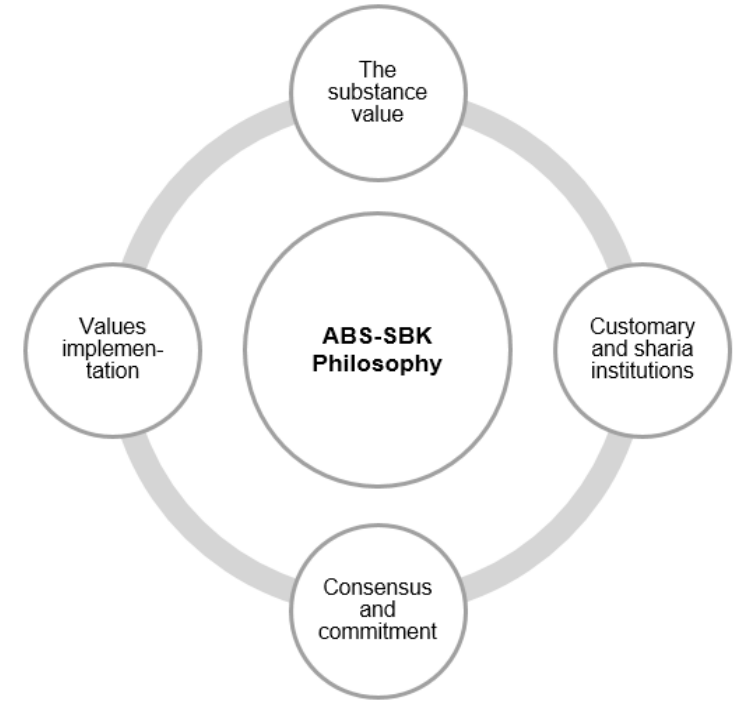

Figure 1.

The determining factors in practicing ABS-SBK philosophy

The $A B S-S B K$ philosophy implementation can reach its optimum goal if every related dimension has a strong unity and complements each other. For instance, both the society and the local government need to know the substance value of this philosophy so that they can fully translate and practice it wisely. There are two values in this case, which are transcendent and profane. These values should not only be heard in the customary speeches but also agreed and recognized as a reference to life for Minangkabau ethnic groups. Meanwhile, in order to maintain and preserve these values, the West Sumatra's social, traditional and sharia institutions, such as the Nagari Indigenous Density and Indonesian Ulama Council, should play a role in the district province level. In addition to that, the Minangkabau Custom and Natural Density Institute also has a significant role to play. The end goal of this study is to get both the local government and the society to implement and practice this philosophy, which is the essence of the $A B S-S B K$ philosophy.

\section{Conclusion}

The ongoing debate about what is $A B S-S B K$ philosophy and how it is found in society has not reached any conclusion. There has not been mutual perception regarding this philosophy; it is a part of the Minangkabau's symbol to reflect the nobleness of their culture and tradition. Some have said, for example, the nagari head, ulamas, and civil society, that this philosophy derives from the Minangkabau's native culture, which called adat nan sabana adat (the true tradition). However, the study results explain that the main problem of the philosophy's implementation is the values in the public sector. The absence of $A B S-S B K$ philosophy is mutually agreed upon guidelines as a consensus of the Minangkabau ethnicity has led to the minimum practice of $A B S-S B K$. It also has had an impact on the consensus that the Minangkabau ethnic group had to agree on these values. Whereas one of the functions of religious and customary institutions and religious institutions is to maintain and preserve the agreed values, the impact is on the interpretation of $A B S-S B K$ philosophical values, which tend to be understood by each based on the obscurity of these values. 
This study recommends some things for both local government and Minangkabau people, which can be implemented regarding the meaning of this $A B S-S B K$ philosophy. First, the value factor of the philosophy itself. This value factor identifies and explores the substantive value of the philosophy. This value could be implemented if the government facilitates guidelines regarding the $A B S-S B K$ philosophy. Second, the religious and traditional institution factor. It is a set of rules which govern Minangkabau's ethnic attitude and behavior and create a balance in the economic, social, cultural, and political conditions in the nagari. The massive increase of global values nowadays causes customs and traditions to conflict with Minangkabau ethics, so that they need to create this consensus as a tool to maintain harmony. Fourth, the other factor is on how the local social practices and absorb this philosophy in their daily lives. This factor is essential because this philosophy remains still relevant to the Minangkabau ethnic group.

\section{Acknowledgement}

This research was conducted at the expense of the Ministry of Research and Technology and the Ministry of Education through the 2017-2018 Basic Research Grant Scheme.

\section{Reference}

Abidin M (2016) Tiga Sepilin: Surau Solusi untuk Bangsa. Yogyakarta: Gre Publishing.

Amir MS (2011) Masyarakat Adat Minangkabau: Terancam Punah Bagai Bajak Ndak Basingka. Jakarta: Citra Harta Prima.

Amran R (1981) Sumatera Barat hingga Plakat Panjang. Jakarta: Sinar Harapan.

Anwar R (2011) Sutan Syahrir: Negarawan Humanis, Demokrat Sejati yang Mendahului Zamannya. Jakarta: Kompas.

Asrinaldi (2017) Demokrasi Lokal di Indonesia: Otonomi, Nagari dan Sosial Budaya di Sumatera Barat. Padang: Erka Publishing.

Asrinaldi, Wannofri S, Yoserizal, Andri R \& Ilham AA (2016) Identifikasi Nilai-Nilai Luhur Adat Basandi Syara', Syara' Basandi Kitabullah dalam Kehidupan Nagari di Kabupaten Solok. Solok: Bappeda Kabupaten Solok.

Asrinaldi \& Yoserizal (2013) Quasi otonomi pada pemerintahan terendah Nagari Simarasok di Sumatera Barat dan Desa Ponjong di Daerah Istimewa Yogyakarta. Sosiohumaniora: Journal of Social Sciences and Humanities 15 (2):178-193. https://doi.org/10.24198/sosiohumaniora. v15i2.5740.

Badan Perencenaan Pembangunan Daerah (2016) Evaluasi Kinerja Pembangunan Daerah Tahun 2015. Padang: Bappeda Sumbar.

Bahar S \& Tadjoeddin MZ (2004) Masih Ada Harapan: Posisi Sebuah Etnik Minoritas dalam Hidup Berbangsa dan Bernegara. Jakarta: Yayasan Sepuluh Agustus.

Croley SP (2008) Regulation and Public Interests: The Possibility of Good Regulatory Government. Princeton: Princeton University Press.

Dzulfikriddin M (2010) Mohammad Natsir dalam Sejarah Politik Indonesia: Peran dan Jasa Mohammad Natsir dalam Dua Orde Indonesia. Bandung: Mizan.

Fithri W (2013) Mau Kemana Minangkabau? Analisis Hermeneutika atas Perdebatan Islam dan Adat Minangkabau. Yogyakarta: Gre Publishing.

Hadler J (2010) Sengketa Tiada Putus: Matriakat, Reformisme Islam, dan Kolonialisme di Minangkabau. Jakarta: Freedom Institute.

Hakimy I (2001) Rangkaian Mustika Adat Basandi Syarak di Minangkabau. Bandung: Remaja Rosdakarya.

Hasanuddin (2013) Adat dan Syarak: Sumber Inspirasi dan Rujukan Nilai Dialektika Minangkabau. Padang: PSIKM.

Latif Y (2011) Negara Paripurna: Historisitas, Rasionalitas, dan Aktualitas Pancasila. Jakarta: Gramedia. 
Navis AA (1984) Alam Terkembang Jadi Guru: Adat dan Kebudayaan Minangkabau. Jakarta: Grafitipers.

Navis AA (2017) Pemikiran Minangkabau: Catatan Budaya A.A. Navis. Bandung: Penerbit Angkasa.

Peters BG (1999) American Public Policy: Promise and Performance. New York: Chotem House/ Seven Rivers.

Poeze HA (2010) Tan Malaka, Gerakan Kiri, dan Revolusi Indonesia. Jakarta: Yayasan Pustaka Obor Indonesia-KITV.

Rose M (2010) Indonesia Free: A Political Biography of Mohammad Hatta. Kuala Lumpur: Equinox Publishing.

Samad D (2018) Merisaukan ABS-SBK, Jawapos, 2 April. [Accessed 30 August 2019]. https://padek. co/koran/padangekspres.co.id/cetak/berita/117041/Merisaukan_ABS_SBK.

Sekretariat Dewan Provinsi Sumatera Barat (2017) Modul penerapan ABS-SBK dengan revolusi mental perlu ada di RPJMD Sumbar. [Accessed 6 October 2017]. http://dprd.sumbarprov. go.id/home/berita/1/448.

Tegnan H (2015) Legal pluralism and land administration in West Sumatra: the implementation of the regulations of both local and nagari governments on communal land tenure. The Journal of Legal Pluralism and Unofficial Law 47 (2):312-323. https://doi.org/10.1080/07329113.2 015.1072386

Vel JAC \& Bedner AW (2015) Decentralisation and village governance in Indonesia: The return to the nagari and the 2014 Village Law. The Journal of Legal Pluralism and Unofficial Law 47 (3):493-507. https://doi.org/10.1080/07329113.2015.1109379.

von Benda-Beckmann F \& von Benda-Beckmann K (2012) Identity in dispute: Law, religion and identity in Minangkabau. Asian Ethnicity 13 (4):341-358. https://doi.org/10.1080/1463136 9.2012.710073.

von Benda-Beckmann F \& von Benda-Beckmann K (2013). Political and Legal Transformations of an Indonesian Polity: The Nagari from Colonisation to Decentralisation. Cambridge: Cambridge University Press.

Weber M (1992) The Protestant Ethic and the Spirit of Capitalism. New York: Routledge. 